\title{
Genetic Variation in Metronidazole Metabolism and Oxidative Stress Pathways in Clinical Giardia lamblia Assemblage A and B Isolates [Corrigendum]
}

\author{
Saghaug CS, Klotz C, Kallio JP, et al. Infect Drug Resist. \\ 2019;12:1221-1235.
}

The authors have advised NR-1 was used throughout the paper to denote the gene named in GiardiaDB as "Nitroreductase family protein fused to ferredoxin domain Fd-NR1" (DHA2_153380/GSB_153178), while in recent literature this is often denoted NR2/GINR2. Likewise, NR-2 was used to denote the gene named in GiardiaDB as "Nitroreductase Fd-NR-2" (DHA2_22677/GSB_22677), while in recent literature this is often denoted NR1/GINR1.
The authors acknowledge that using the NR gene names as annotated in GiardiaDB may cause confusion and therefore, bring this to the attention of readers that more correctly what is named "NR-1" in the paper should be read as "NR-2", and "NR-1" should be read as "NR-2".

The authors apologize for not having considered this issue in the original manuscript.

\section{Publish your work in this journal}

Infection and Drug Resistance is an international, peer-reviewed openaccess journal that focuses on the optimal treatment of infection (bacterial, fungal and viral) and the development and institution of preventive strategies to minimize the development and spread of resistance. The journal is specifically concerned with the epidemiology of antibiotic resistance and the mechanisms of resistance development and diffusion in both hospitals and the community. The manuscript management system is completely online and includes a very quick and fair peerreview system, which is all easy to use. Visit http://www.dovepress.com/ testimonials.php to read real quotes from published authors. 